\title{
KONTEKS TUTURAN BAHASA HUMOR DALAM AKUN YOUTUBE MAJELIS LUCU INDONESIA PADA "KONTEN DEBAT KUSIR"
}

\author{
Deny Sulistyawati ${ }^{1}$, Markhamah $^{2}$, Atiqa Sabardila ${ }^{3}$ \\ ${ }^{1-3}$ Magister Pendidikan Bahasa Indonesia, Universitas Muhamamdiyah Surakarta, Indonesia
}

DOI: 10.23917/humaniora.v20i2.9102

Submit: 26 Oktober 2019. Revisi: 28 Juli 2020. Diterima: 10 Agustus 2020.

Available Online: 21 Agustus 2020. Periode Terbit: Agustus 2020

\begin{tabular}{|c|c|}
\hline Kata Kunci & Abstrak \\
\hline $\begin{array}{l}\text { impoliteness, } \\
\text { the context of the speech, } \\
\text { youtube }\end{array}$ & $\begin{array}{l}\text { This study was aimed to explore the context of speech found in } \\
\text { Majlis Lucu Indonesia You tube account in the content of debat } \\
\text { kusir. The data were in the form of utterances collected from } \\
\text { six videos entitled "Membantah Argument Deddy Corbuzier," } \\
\text { "Respect Reza Octovian," "Atta Halilintar Tidak Bersalah," }\end{array}$ \\
\hline $\begin{array}{l}\text { Corresponding } \\
\text { Author }\end{array}$ & $\begin{array}{l}\text { "Lagi-Lagi Atta Halilintar," "Cara MenaklukanDeddyCor- } \\
\text { buzier," dan "TausiyahUntuk K-Poppers." The research ap- }\end{array}$ \\
\hline $\begin{array}{l}\text { Nama: Deny Sulistya- } \\
\text { wati } \\
\text { Universitas Muham- } \\
\text { madiyah Surakarta, } \\
\text { Indonesia } \\
\text { Email: } \frac{\text { denysulistya- }}{\text { wati456@gmail.com }} \\
\text { Telp: }+6285799416005\end{array}$ & $\begin{array}{l}\text { proach was descriptive qualitative, particularly the reference } \\
\text { and the documentary method. The data collection techniques } \\
\text { used were listening, note-taking, and documentary techniques. } \\
\text { The result indicated that there were five contexts in this study, } \\
\text { namely, describing contextual contexts, existential contexts, } \\
\text { situational contexts, practical contexts, and psychological con- } \\
\text { texts. }\end{array}$ \\
\hline
\end{tabular}

\section{PENDAHULUAN}

Ilmu pengetahuan dan penelitian saling menunjang untuk mencapai tujuan yang sama. Penelitian adalah penggunaan metode ilmiah yang bersifat formal dan sistematis untuk mempelajari sesuatu masalah (Darmadi, 2013: 04). Komunikasi digunakan untuk berinteraksi antara seseorang dengan orang lain. Seseorang akan mendapatkan banyak pengetahuan dan wawasan melalui komunikasi. Komunikasi digunakan untuk menyampaikan maksud dan tujuan. Terdapat banyak hal yang dapat dikaji dalam berkomunikasi, baik langsung atau tidak langsung antarindividu. Parret (dalam Wulandari, 2010:179) membedakan konteks tutur menjadi lima macam, yaitu (a) konteks kontekstual, (b) konteks eksistensial, (c) konteks situasional, (d) konteks aksional, dan (e) konteks psikologis. Konteks kontekstual adalah konteks yang berupa koteks, yakni perluasan cakupan tuturan seseorang yang menghasilkan teks. Konteks eksistensial adalah partisipan (orang), waktu, dan tempat yang mengiringi tuturan, misalnya siapa yang menuturkan dan kepada siapa tuturan itu ditujukan, kapan, dan di mana tempatnya. Konteks situasional adalah jenis faktor penentu kerangka sosial institusi yang luas dan umum, seperti pengadilan, rumah sakit, ruang kelas, atau latar kehidupan sehari-hari, misalnya pasar, ladang, dan lain-lain, yang memiliki kebiasaan dan atau percakapan khas. Konteks aksional adalah tindakan, aksi, atau perilaku-perilaku nonverbal yang menyertai penuturan, misalnya menarik nafas dalam-dalam, menatap, membusungkan dada, dan lainlain. Konteks psikologis adalah situasi psikis dan mental yang menyertai penuturan, seperti marah, gembira, bersemangat, dan sebagainya. 
Humor tercipta karena adanya bahasa yang mengiringgi kata. Humor digunakan untuk meredakan ketegangan dan memberikan dampak yang baik bagi interaksi berikutnya karena apabila setelah diberi rangsangan humor, seseorang dapat merasakan kembali kesegaran dalam pikirannya. Hal tersebut menunjukkan bahwa humor dapat mencairkan suasana dan kreativitas bagi pencipta dan penerima humor.

Penelitian mengenai humor telah diteliti dalam beragam opini. Julianto (2012) dalam judul "Teater Rakyat sebagai Media dalam Seni Pertunjukan Lenong Betawi" menemukan bahwa humor adalah bentuk ekspresi dari kondisi yang sudah lama tertekan. Beberapa penelitian terkait humor yang sudah dilaksanakan antara lain aspek bunyi sebagai sarana kreatifitas humor (Hermintoyo; 2012), strategi penciptaan humor sebagai pemanfaatan aspek-aspek kebahasaan (Muhammad; 2012), pemanfaatan teks humor dalam pengajaran aspek-aspek kebahasaan (Wijana; 2013).

Penelitian mengenai konteks telah diteliti dalam ragam opini. Balfas (2008) dalam penelitiannya yang berjudul "Mengembangkan Kemampuan Literasi dan Kritis Berfikir Siswa melalui Pembelajaran Sastra Berbasis Konteks" menemukan bahwa pembelajaran sastra berbasis konteks bertujuan untuk menerapkan pengalaman belajar untuk penggunaan dan kebutuhan praktis. Beberapa penelitian terkait dengan konteks yang sudah dilakukan antara lain verba fungsional distribusi dalam wacana narasi dongeng bahasa Indonesia (Poerwadi, 2010), masuk angin dalam konteks kosmologi Jawa (Triatnawati, 2011), mengungkapkan masa depan: inovasi pembelajaran bahasa Indonesia dalam konteks pengembangan karakter cerdas (Atmazaki; 2009). Analisis konteks tutur yang digunakan adalah konteks yang terdapat dalam akun Youtube. Penelitian ini membahas konteks tutur yang terdapat dalam akun Majelis Lucu Indonesia dalam "Konten Debat Kusir".

\section{METODE}

Penelitian ini menggunakan pendekatan deskripstif kualitatif. Wujud data dalam penelitian berupa tuturan dalam akun Youtube Majelis Lucu Indonesia. Wujud data berupa hasil transkipsi dari video Youtube dalam akun Majelis Lucu Indonesia atau lebih spesitif pada "Konten Debat Kusir". Sumber data dalam penelitian ini adalah dokumen. Dokumen yang dipakai berwujud sebuah. Metode pengumpulan data menggunakan metode simak dan metode dokumenter. Keabsahan data menggunakan teknik triangulasi dokumen. Teknik analisis data menggunakan teknik padan pragmatik..

\section{HASIL}

Berdasarkan tujuan penelitian, berikut dapat dijabarkan hasil penelitian berupa konteks tutur dalam akun Youtube Majelis Lucu Indonesia dalam "Konten Debat Kusir" meliputi enam video yaitu "Membantah Argumen Deddy", "Respect Reza Octovian", "Atta Halilintar Tidak Bersalah", "Lagi-Lagi Atta Halilintar", "Cara Menaklukan Deddy Corbuzier", dan "Tausiyah untuk K-Popers".

Tabel 1. Analisis Konteks Kontekstual dalam Akun Youtube Majelis Lucu Indonesia dalam "Konten Debat Kusir" Konteks Kontekstual

\section{Membantah Argumen Deddy Corbuzier}

1. Coki dan Trestan menyampaikan tujuan dari video yang dibuat yaitu Debat kusir yang berjudul "Membantah argumen Deddy Corbuzier".

2. Seseorang yang memiliki jumlah pengikut banyak serta mempunyai pengaruh kuat bagi pengikut mereka.

3. Menunjukkan alasan membahas Deddy

4. Kondisi ini yang menjadikan perluasan cakupan tuturan.

\section{Respect Reza Octovian}


5. Kondisi ini yang menjadikan perluasan cakupan tuturan.

(Tuturan ditujukan kepada Reza Octovian)

\begin{tabular}{ll}
\hline Atta & Tidak Bersalah \\
\hline $6 . \quad$ Kondisi ini yang menjadikan perluasan cakupan tuturan. \\
(Tuturan ditujukan kepada Atta Halilintar) \\
7. $\quad$ Berkata sambil menjelaskan alasan membahas Atta Halilintar \\
$8 . \quad$ Trestan menyampaikan keluhan nitijen \\
\hline Lagi-lagi Atta Halilintar \\
\hline $9 . \quad$ Alasan membahas Atta dalam video \\
\hline Cara Menaklukan Deddy Corbuzier \\
\hline 10. Tuturan ditujukan kepada Deddy Corbuzier. \\
\hline Tausiyah untuk K-Popers \\
\hline $11 \quad$ Tuturan ditujukan kepada k-popers \\
\hline
\end{tabular}

Berdasarkan analisis konteks tutur dalam video Majelis Lucu Indonesia dalam "Konten Debat Kusir" tuturan yang menunjukkan konteks kontekstual karena menunjukkan alasan dari pembuatan setiap video sehingga menghasilkan cakupan tuturan yang menghasilkan teks. Hasil analisis data konteks kontekstual menunjukkan secara umum konteks kontekstual dimunculkan dalam setiap video, yaitu sebelas tuturan yang ditemukan. Salah satunya dalam judul "Membantah Argumen Deddy Corbuzier" menunjukkan perluasan cakupan tuturan seseorang antara Coki dan Trestan yang menyampaikan tujuan dari video yang digunakan sebagai pengantar kepada para penonton dengan mendeskripsikan cara kerja Coki dan Trestan ketika menggungkapkan pandangannya tentang seseorang yang sedang dibicarakan. Hal tersebut dibuktikan dengan kalimat "Kita akan membuat nitijen atau warganet membuka matanya, kepada pandangan-pandangan yang kita berikan".

Tabel 2. Analisis Konteks Eksistensial dalam Akun Youtube Majelis Lucu Indonesia dalam "Konten Debat Kusir" Konteks Eksistensial

\begin{tabular}{ll}
\hline Membantah Argumen Deddy Corbuzier \\
\hline 1. & Tuturan ditujukan kepada genk Halilintar. \\
2. & Tuturan ditujukan kepada Deddy Corbuzier dan Ria Ricis. \\
3. & Tuturan ditujukan kepada Deddy Corbuzier sebagai topik pembicaraan. \\
\hline Respect Reza Octovian \\
\hline 4. & Tuturan disampaikan oleh Coki dan Trestan Muslim \\
5. & Tuturan ditujukan kepada Deddy Corbuzier. \\
6. & Tuturan ditujukan kepada Young Lex. \\
7. & Tuturan ditujukan kepada Cameo. \\
\hline
\end{tabular}

\section{Atta Tidak Bersalah}

8. Tuturan ditujukan kepada Atta Halilintar

9. Tuturan ditujukan kepada penyelengara acara meat and great di lingkungan masjid (Tuturan ini ditujukan kepada Atta Halilintar)

\section{Lagi-lagi Atta Halilintar}

10. Tuturan ini ditujukan kepada Atta Halilintar

11. Tuturan ini ditujukan kepada Awkarin

Cara Menaklukan Deddy Corbuzier

12. Tuturan ditujukan kepada Cemeo Project

13. Tuturan ditujukan kepada Deddy Corbuzier

\section{Tausiyah untuk K-Popers}

14. Tuturan ditujukan kepada artis korea 
15. Berkata dengan memperkenalkan diri

Konteks eksistensial menunjukkan partisipan (orang), waktu, dan tempat yang dapat mengiringi tuturan. Konteks eksistensial juga dimunculkan dalam setiap video, yaitu lima belas tuturan yang mengandung unsur konteks eksistensial. Hasil analisis data konteks eksistensial menunjukkan pada sub konten "Membantah Argumen Deddy Corbzier" dipublikasikan oleh Majelis Lucu Indonesia tanggal 04 September 2018. Reaksi video ditujukkan sebagai tanggapan terhadap argumen yang dilontarkan oleh Deddy Corbuzier tentang penggunaan sosial media.

Tabel 3. Analisis Konteks Situasional

dalam Akun Youtube Majelis Lucu Indonesia dalam "Konten Debat Kusir"

\begin{tabular}{ll}
\hline Membantah Argumen Deddy Corbuzier \\
\hline 1. & Penggunaan sosial media \\
2. & Hak setiap orang untuk menggunakan sosial media \\
\hline
\end{tabular}

\section{Atta Tidak Bersalah}

3. Menujukan nama tempat ibadah "masjid"

4. Menujukan nama tempat "upnormal"

9 Membandingkan dengan sesuatu yang dianggap berbeda jalur "mata najwa"

10. Tuturan ditujukan kepada Atta Halilintar

\section{Lagi-lagi Atta Halilintar}

11. Gambaran situasi kehidupan Youtube

12. Gambaran situasi di mobil

\section{Cara Menaklukan Deddy Corbuzier}

13. Menunjukkan suasana ruang tamu Deddy

14. Menunjukkan salah satu tempat makan cepat saji

Konteks situasional sebagai penentu kerangka sosial terdapat di sosial media, khususnya Youtube dan tidak semua memunculkan kekhasan dalam setiap video. Kekhususan dalam video "Membantah Argumen Deddy Corbuzier" adalah Coki dan Trestan merasa kurang sependapat dengan argumen yang diungkapkan oleh Deddy Corbuzier terhadap penggunaan sosial media.Berdasarkan enam video yang dianalisis konteks situasional tidak ditemukan dalam video "Respect Reza Octovian", dan "Tausiyah untuk K-Popers".

Tabel 4. Analisis Konteks Aksional

dalam Akun Youtube Majelis Lucu Indonesia dalam "Konten Debat Kusir"

\begin{tabular}{ll}
\hline Membantah Argumen Deddy Corbuzier \\
\hline 1. & Sambil melambaikan tangan \\
2. & Sambil melipat tangan \\
3. & Gerakan tinju. \\
4. & Berkata sambil mempraktikan kegiatan bertinju
\end{tabular}

\section{Respect Reza Octovian}

5. Berkata sambil membelai rambut sendiri.

6. Berkata dengan mengerakan tangan seperti angsa

7. Berkata dengan menunjuk-nunjuk jari

(Tuturan ditujukan kepada Cameo)

\begin{tabular}{ll}
\hline Atta & Tidak Bersalah \\
\hline $8 . \quad$ Menujukkan gerakan dan ekspresi yang mengemaskan
\end{tabular}




\begin{tabular}{ll}
\hline & (Tuturan ini ditujukan untuk memberikan kesan kurang baik) \\
9. & Berkata dengan menunjuk-nunjuk jari \\
10. & Berkata sambil tangan menunjuk ke arah belakang \\
\hline Lagi-lagi Atta Halilintar \\
\hline $11 . \quad$ Menujukan sikap mengoda \\
12. $\quad$ Menujukan ekspresi mengejek \\
13. $\quad$ Menujukan ekspresi tengil \\
14. $\quad$ Coki dan Trestan memperagakan seseorang ketika bernyanyi "RAP” \\
15. $\quad$ Berkata sambil mengeleng-gelengkan kepala \\
16. $\quad$ Menegaskan kembali dengan gerakan ketika makan \\
\hline Cara Menaklukan Deddy Corbuzier \\
\hline 17. $\quad$ Berkata sambil membuat gerakan memutar-mutarkan kepala \\
\hline
\end{tabular}

Data di atas menunjukkan konteks aksional tidak semua memunculkan bentuk kegiatan nonverbal serta penuh dengan aksi nonverbal. Hasil analisis data konteks aksional menunjukkan konten aksional tidak semua memunculkan bentuk kegiatan nonverbal. Satu video yang tidak menunjukkan kegiatan nonverbal yaitu dalam video "Tausiyah untuk K-Popers". Berdasarkan hal tersebut ditemukan tujuh belas konteks aksional dari lima video yang dianalisis. Konteks aksional berupa kegiatan melambaikan tangan, melipat tangan, dan menirukan gerakan tinju ditunjukkan video "Membantah Argumen Deddy Corbuzier". Selain itu, ditemukan kegiatan sambil membelai rambut. Contoh data kegiatan melambaikan tangan menunjukkan sebuah tindakan yang dilakukan oleh Coki ketika menuturkan salah satu kebiasaan dari sesorang yang sedang dibicarakan, yaitu Deddy Corbuzier. Perilaku nonverbal dalam tersebut berupa tindakan berkata sambil melambaikan tangan untuk mengoda seseorang yang dibicarakan. Hal tersebut dibuktikan dalam kalimat "Saya suka mascara Om yang dulu". Deddy dahulu ketika menjadi pesulap identik dengan mancara hitam yang digunakan di kelopak mata dan rambut panjang. Namun, setelah berhenti menjadi pesulap Deddy meninggalkan hal tersebut, kini Deddy tampil tanpa mascara dengan kepala gundul.

Tabel 5. Analisis Konteks Psikologi dalam Akun Youtube Majelis Lucu Indonesia dalam "Konten Debat Kusir" Konteks Psikologi

\begin{tabular}{ll} 
Membantah Argumen Deddy Corbuzier \\
1. \\
2. & Corkata sambil kesal \\
3. & Berkata dengan nada tinggi \\
4. & Suaranya tegas dan mengangukan kepala utk membenarkan sesuatu \\
\hline
\end{tabular}

Respect Reza Octovian

\begin{tabular}{ll} 
5. & Berkata sambil mengejek \\
6. & Berkata dengan penuh semangat \\
7. & Gembira \\
\hline
\end{tabular}

\begin{tabular}{ll}
\hline Atta & Tidak Bersalah \\
\hline 8. & Bertanya gusar \\
9. & Gembira \\
10. & Berkata dengan penuh semangat dan bernada tinggi dengan tujuan mengejek \\
11. & Bersemangat dan penuh keyakinan \\
12. & Trestan merasa heran \\
13. & Mencoba meluruskan \\
14. & Mencoba memahami kembali \\
15. & Mencoba meyakinkan lawan tutur \\
16. & Berkata dengan lantang
\end{tabular}


17. Berkata dengan nada tinggi dan jengkel

18. Coki berkata dengan berulang

19. Membenarkan dengan mengulang kata

20. Menegaskan kembali

21. Tegas

22. Merendahkan diri sendiri

23. Memuji

Cara Menaklukan Deddy Corbuzier

24. Mencoba menjelaskan

25. Menunjukkan ekspresi kegembiraan

26. Tuturan disampaikan dengan penuh kegembiraan

\section{Tausiyah untuk K-Popers}

27. Tuturan disampaikan dengan kekesalan

28. Tuturan disampaikan dengan nada tinggi dan penuh kekesalan

29. Tuturan disampaikan dengan kegembiraan

30. Berkata dengan penuh kegembiraan

31 Berkata dengan kalimat berupa tantangan

Konteks psikologis dalam video Majelis Lucu Indonesia dalam "Konten Debat Kusir" tuturan mengungkapkan situasi psikis dan mental yang menyertai tuturan. Hasil analisis data secara umum konteks psikologis ditemukan tiga puluh satu data yang ditemukan dalam lima video namun satu video tidak ditemukan konteks psikologis yaitu video "Lagi-lagi Atta Halilintar". Konteks psikologis ditunjukkan dalam bentuk kekesalan, berkata dengan nada tinggi, bersuara tegas, gembira, gusar, penuh keyakinan, mencoba meluruskan, dan tantangan. Konteks psikologis yang menunjukkan kekesalan ditunjukkan dalam video "Membantah Argumen Deddy Corbuzier" yang tuturan tersebut disampaikan oleh Trestan yang mengungkapkan kesedihan dalam kalimat "Aku lagi sakit ini nih, aku lagi sedih gimana dong?" Tuturan tersebut muncul sebagai bentuk kekesalan Trestan ketika seseorang curhat di sosial media hanya separuh-separuh tidak seutuhnya sehingga membuat seseorang yang membaca merasa penasaran dan kesal. Hal tersebut dibuktikan dalam kalimat "Ya gitu, yang ngeselin itu kalau dia curhat separuh-separuh".

\section{PEMBAHASAN}

Konteks tutur dalam akun Youtube Majelis Lucu Indonesia pada "Konten Debat Kusir" menggunakan 5 konteks tutur. Konteks kontekstual, Konteks eksistensial, Konteks situasional, Konteks aksional, dan Konteks psikol. Napoli (2012) menyatakan bahwa humor dikaitkan dengan pengalaman visual yang dominan dari orang tuli, tetapi juga dipengaruhi oleh pengetahuan mereka tentang tradisi humor dalam masyarakat pendengaran pada umumnya. Hasilnya menunjukkan humor bahasa di Amerika dan Inggris dapat dilihat dalam penciptaan tanda-tanda visual baru. Adapun hasil penelitian ini adalah peneliti menemukan humor yang dikemas dalam sebuah video yang digunakan untuk membuat suasana menjadi lebih hangat dengan menyelipkan humor dalam sebuah percakapan.

Effendy (2014) membandingkan konteks tindak tutur bahasa Madura pada lingkungan keluarga dari yang berpendidikan, tokoh masyarakat, lingkungan keluarga tidak berpendidikan, Pratama (2013) menyimpulkan konteks yang didayagunakan oleh anak. Perbedaan penelitian Effendy (2014) dan Pratama (2013) dan penelitian ini adalah hasil temuannya. Penelitian ini menemukan konteks tutur yang berupa konteks kontekstual, konteks eksistensial, konteks situasional, konteks aksional, dan konteks psikologis. Persamaan penelitian Effendy (2014), Pratama (2014) adalah keduanya mengkaji humor.

Muhana (2004) membandingkan pengajaran literasi dan penilaian portofolio dalam konteks pembelajaran menulis. Imam (2011) menyimpulkan pembelajaran kontekstual. Ngatmini (2009) membandingkan pembelajaran sastra yang efektif, kontekstual dan 
inovatif. Wahyu (2012) mengungkapkan konteks dalam membangun karakter siswa sekolah dasar. Perbedaan penelitian Muhana (2004), Imam (2011), Ngatmini (2009), dan Wahyu (2012) adalah hasil temuannya. Penelitian ini menggunakan konteks tutur yang digunakan untuk mengkaji sebuah video untuk mengetahui alasan pembuatan video sampai dengan situasi psikis yang menyertai tuturan tersebut. Persamaan penelitian Muhana (2004), Imam (2011), Ngatmini (2009), dan Wahyu (2012) adalah keduanya mengkaji konteks.

Manuati (2008) membandingkan strategi berupa dimensi, faset, konteks, dan domain. Kweldju (2009) menyimpulkan konstruk kecakapan berbahasa dalam konteks penelitian. Nurhakim (2005) memaknai agama dalam partai politik pada konteks reformasi studi perbandingan di partai politik. Perbedaan penelitian Manuati (2008) dan Kweldju (2009) adalah hasil temuannya. Penelitian ini menggunakan konteks tutur yang digunakan untuk mengkaji sebuah video untuk mengetahui alasan pembuatan video sampai dengan situasi psikis yang menyertai tuturan tersebut. Persamaan penelitian Manuati (2008) dengan Kweldju (2009) adalah keduanya mengkaji konteks.

\section{SIMPULAN}

Konteks tutur yang dianalisi dalam tuturan ketidaksantunan bahasa humor dalam akun Youtube Majelis Lucu Indonesia mengandung lima konteks, yakni konteks kontekstual, eksistensial, situasional, aksional, dan konteks psikologis.

\section{DAFTAR PUSTAKA}

Atmazaki. (2009). Mengungkapkan Masa Depan: Inovasi Pembelajaran Bahasa Indonesia dalam Konteks Pengembangan Karakter Cerdas. Jurnal Artikulasi. 8(2), 434-452. Diakses pada 22 Oktober 2019. (http://id.portalgaruda.org/index.php?ref=browse\&mod=viewarticle \&article $=97397$ )

Darmadi, H.(2013). Dimensi-dimensi Merode Penelitian Pendidikan dan Sosial: Konsep Dasar dan Implementasi. Bandung: Alfabeta.

Effendy, M. H. (2014). "Analisis Kearifan Lokal dalam Konteks Tindak Tutur Bahasa Madura”. Jurnal Okara. 2(9), 19-44 . Diakses pada 19 Oktober 2019. (http://id.portalgaruda.org/index.php?ref=browse\&mod=viewarticle \&article=3283)

Hermintoyo. ( 2012). “Aspek Bunyi sebagai Sarana Kreatvitas Humor”. Jurnal Kajian Sastra. 35(1), 14-27. Diakses pada 22 Oktober 2019. (http://id.portalgaruda.org/index.php?ref=browse\&mod=viewarticle\&article=23142 )

Imam, K..(2011). "Keefektifan Pembelajaran Kontekstual berorientasi peneluan berbantuan CD Pembelajaran dan LKS pada Materi Bilangan Bulat di Sekolah Dasar. Jurnal Majalah Ilmiah Sultan Agung, 49 (123) ,1-14. Diakses pada 21 Oktober 2019 (http://jurnal.unissula.ac.id/index.php/majalahilmiahsultanagung/article/view/34)

Julianto, I. (2012). Teater Rakyat sebagai Media Kritik Sosial: Fungsi humor dalam Seni Pertunjukan Lenong Betawi. Jurnal Humaniora. 18(1), 7-14, Diakses pada 22 Oktober 2019. http://doi.org/10.22146/jh.858

Kweldju, S. (2009). Konstruk Kecakapan Berbahasa dalam Konteks Penelitian. Jurnal Penelitian Kependidikan. 6 (1): 236-246. Diakses pada 21 Oktober 2019. (http://id.portalgaruda.org/index.php?ref=browse\&mod=viewarticle\&arti$\mathrm{cle}=56016)$

Manuati, D. (2008). Strategi: Dimensi, Faset, Konteks, dan Domain. Fokus Ekonomi, 7(2), 37-48. Diakses pada 21 Oktober 2019. (http://id.portalgaruda.org/index.php?ref=browse\&mod=viewarticle\&article=7774)

Muhammad. (2012). Strategi Penciptaan Humor dengan Pemanfaatan Aspek Kebahasan. Jurnal Humaniora. 22(3), 285-298 . Diakses pada 22 Oktober 2019. (http://id.portalgaruda.org/index.php?ref=browse\&mod=viewarticle\&article=2833 )

Muhana, G. (2004). Pengajaran Literasi dan Penilaian dalam Konteks Pembelajaran 
Menulis di SD. Jurnal Ilmu Pendidikan. 11(1), 1-12. Diakses pada 21 Oktober 2019.

Napoli, R, S. (2012). Deaf Jokes and Sign Language Humor. International Journal of Humor Research, 25(3), 311-337.. Diakses pada 08 November 2018 (https//scholar.google.co.id).

Nurhakim. (2005). Pemaknaan Agama dalam Partai Politik dalam Konteks Reformasi Studi Perbandingan PPP, PKB, dan PAN. Jurnal Humanity. 1(1), 61-68. Diakses pada $22 \quad$ Oktober $2019 . \quad$ (http://id.portalgaruda.org/index.php?ref=browse\&mod=viewarticle\&article $=98151$ )

Ngatmini. (2009). Pembelajaran Sastra yang Efektif, Kontekstual, dan Inovatif. Majalah Ilmiah Lontar. 23(4): 117-126. Diakses pada 21 Oktober 2019. (http://id.portalgaruda.org/index.php?ref=browse\&mod=viewarticle\&article=7103)

Poerwadi, P. (2010). Verba Fungsional Distribusi dalam Wacana Narasi Dongeng Bahasa Indonesia. Jurnal Linguistika. 17(33), 1-19. Diakses pada 22 Oktober 2019. (http://id.portalgaruda.org/index.php?ref=browse\&mod=viewarticle\&arti$\mathrm{cle}=16539)$

Pratama. (2014). Pendayagunaan Konteks dalam Tindak Tutur Anak Tujuh Tahun dan Implikasinya pada Pembelajaran. Jurnal Pendidikan Bahasa dan Sastra Indonesia FKIP Universitas Lampung. 1 (7), 1-11. Diakses pada 19 Oktober 2019. (http://id.portalgaruda.org/index.php?ref=browse\&mod=viewarticle\&article $=3623)$

Wahyu, W. (2012). Implementasi Pendidikan Ramah Anak dalam Konteks Membangun Karakter Siswa di Sekolah Dasar Negeri di Kota Semarang. Majalah Ilmiah Lontar. 6(1), 222-236. Diakses pada 21 Oktober 2019. (http://id.portalgaruda.org/index.php?ref=browse\&mod=viewarticle\&article=7121)

Wulandari, Y. (2014). Ketidaksantunan Berbahasa Tokoh dalam Cerpen Harga Seorang Perempuan Karya Oka Rusmini: Analisis Bentuk Pelanggaran Maksim Tuturan Tokoh dalam Karya Sastra sebagai Materi Autentik Pembentukan Karakter. Prosiding Seminar Nasional. ISBN: 978-979-636-156-4:174-184. Diakses pada 08 November 2018. (https://publikasiilmiah.ums.ac.id/xmlui/bitstream/handle/11617/4361/19.\%20Yosi\%20Wulandari.pdf?sequence=1\&isAllowed=y)

Wijana, I D, P. (2013). Pemanfaatan Teks Humor dalam Pengajaran Aspek-Aspek Kebahasaan. Jurnal Humaniora. 11(1), 23-30. Diakses pada 22 Oktober 2019. (http://id.portalgaruda.org/index.php?ref=browse\&mod=viewarticle\&article $=93486$ ) 